\title{
Central Scandinavian winter precipitation variability during the past five centuries reconstructed from Pinus sylvestris tree rings
}

HANS W. LINDERHOLM AND DELIANG CHEN

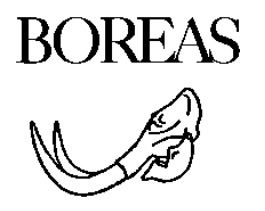

\begin{abstract}
Linderholm, H. W. \& Chen, D. 2005 (February): Central Scandinavian winter precipitation variability during the past five centuries reconstructed from Pinus sylvestris tree rings. Boreas, Vol. 34, pp. 43-52. Oslo. ISSN 0300-9483.

Using Scots pine (Pinus sylvestris L.) tree-ring data, winter (September-April) precipitation variability in west central Scandinavia was reconstructed for the past five centuries. The main growth-limiting factor for pine growing in the studied area is summer temperature, but there is an additional influence of precipitation. Using principal components analysis on three tree-ring-width chronologies, a time series was yielded that contained information on winter precipitation $\left(\mathrm{P}_{\mathrm{w}}\right)$. Using tree rings, only a small part $(20 \%)$ of the interannual $\mathrm{P}_{\mathrm{w}}$ variability could be explained. However, better agreement between the modelled and measured $\mathrm{P}_{\mathrm{w}}$ data on semidecadal time scales $(45 \%$ variance explained) suggests that tree-ring data from the west-central part of Scandinavia contain useful information on those time scales. The driest winters, disregarding the absolute beginning of the record, were found at the beginning of the 18th century; the last half of the 20th century seems to be the wettest, at least for the past 400 years. Since our precipitation reconstruction agrees fairly well with previously published precipitation proxies, it is suggested that tree rings may add useful information to future multi-proxy reconstructions.
\end{abstract}

Hans W. Linderholm* (e-mail: hansl@gvc.gu.se),Deliang Chen (e-mail: deliang@gvc.gu.se), Regional Climate Group, Department of Earth Sciences, Gothenburg University, SE-405 30 Gothenburg, Sweden. *Also: Laboratory for Climate Studies, National Climate Center, China Meteorological Administration, 46 Zhongguancun Nandajie, Haidian, Beijing 100081, China; received 9th March 2004, accepted 27th August 2004.

Tree-ring data from high latitudes are frequently used as temperature proxies and have helped to enhance our understanding of past temperature variability (Mann et al. 1999; Crowley 2000; Jones et al. 2001; Esper et al. 2003; Mann \& Jones 2003). However, there is a need for information on precipitation as well, since increasing temperatures are expected to accompany changes in precipitation patterns (IPCC 2001). Evidence indicates that Scandinavia has become increasingly milder and wetter over the past few decades (Hanssen-Bauer \& Førland 1998; Tuomenvirta et al. 2000; Busuioc et al. 2001) and this is likely to have a considerable impact on various ecosystems, marine as well as terrestrial (Crawford 2000).

In the central Scandinavian Mountains, tree growth is limited mainly by temperature during the growing season (Kalela-Brundin 1999; Gunnarson \& Linderholm 2002; Solberg et al. 2002; Linderholm et al. 2003). Tree-ring data have not therefore been regarded as suitable for annually resolved precipitation reconstructions. However, owing to proximity to the North Atlantic, the climate in west-central Scandinavia ranges from oceanic to sub-oceanic and, consequently, precipitation has a pronounced effect on tree growth in this area. It has been suggested that the weather conditions of the winter prior to the growing season may have significant impact on the subsequent year's tree growth in central Scandinavia (Linderholm 2002). Although pines are dormant during winter, climate conditions during that period may affect growth conditions at a later stage, e.g. high winter temperatures may cause growth stress if mild periods break the dormancy (Kirchhefer 1999). In addition, high amounts of snow in winter can lead to sustained snow cover lasting well into late spring, and this causes later initiation of cambial activity (Vaganov et al. 1999). Another possible effect of snow cover is delayed thawing of the soil in spring, when evapotranspiration increases due to increasing air temperature, causing trees to suffer from frost drought (Thomsen 2001). Furthermore, mild spells in winter, with precipitation falling as rain rather than snow, would increase the likelihood of snow-free periods, particularly at low elevations (Mysterud et al. 2000) and therefore the ground is exposed to frost in following cold periods. This could lead to both a prolongation of ground frost in spring and to winter desiccation (Tranquilini 1979). Deep ground frost in cold winters with thin snow cover may also lead to winter desiccation and needle loss (Kullman 1991). Consequently, information on winter precipitation is most likely incorporated in tree-growth variability.

In this article, an attempt is made to relate Scots pine (Pinus sylvestris L.) tree-ring data to winter (September to April) precipitation. The main objective is to determine the extent to which the tree-ring data can reflect winter precipitation on various temporal scales. When useful information about precipitation can be obtained, a reconstruction of precipitation is 


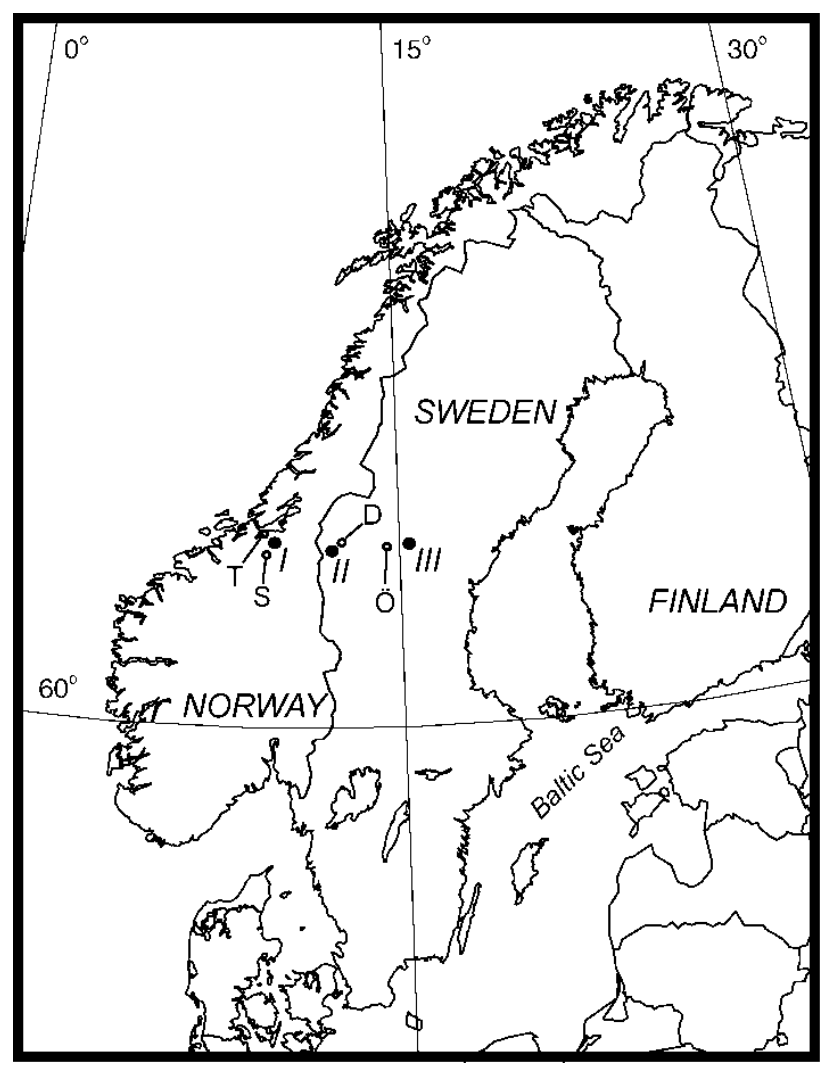

Fig. 1. Map of the study area. Tree-ring data used in this investigation come from I: Nonahaugen, II: Handölan-Håckren, III: Tannsjö. Also shown are the locations of the meteorological stations used to show the climate gradient in the study area (see Fig. 2): $\mathrm{T}=$ Trondheim; $\mathrm{S}=$ Selbu; $\mathrm{D}=$ Duved $; \ddot{\mathrm{O}}=$ Östersund.

made. Since summer temperature is the dominant growth-controlling factor for the growth of Scots pine in this region, it is not expected that the tree-ring data capture the full range of precipitation variability on interannual time scales. Nevertheless, some precipitation information may be revealed if appropriate analysis methods are chosen. Using principal components analysis, information on winter precipitation for the past five centuries is presented and compared to previously published data.

\section{Study area}

The tree-ring data used in this study come from an area located within the Northern Boreal zone in central Scandinavia (Fig. 1), which is dominated by the main divide of the Scandinavian Mountains. From west to east there is a gradual change in the climate, i.e. from maritime on the west side of the mountains to subcontinental on the east (based on temperature and precipitation; Fig. 2). Consequently, the climate west of the Scandinavian Mountains is characterized by mild and wet winters and cool summers with the highest precipitation in autumn and winter. Owing to low topography of the local main divide of the mountains, maritime air masses can easily penetrate the central parts of the study area. This causes the area at and just east of the main divide to have a moister and milder climate than expected; it may be characterized as suboceanic. Further east of the mountains, climate is subcontinental, characterized by colder winters, warm summers and considerably lower precipitation, with a maximum in summer and autumn. The strong impact of the westerlies is responsible for the oceanic climate in the west, but sites east of the Scandinavian Mountain range are also influenced by Atlantic air masses.

\section{Material and methods}

\section{Tree-ring data}

Three Scots pine tree-ring-width chronologies were used to evaluate the possibilities of using central Scandinavian tree-ring data to reconstruct precipitation (Fig. 1): Nonshaugen, Norway, (site I), HandölHåckren, Sweden (site II) and Tannsjö, Sweden (site III). Sites I and III were situated at the western and eastern foot of the Scandinavian Mountains, respectively, and site II at the pine-tree line close to the main divide of the mountains (Table 1). All chronologies consist of samples from a minimum of 26 trees (26-38 trees) from living, mature and old Scots pines from scattered stands close to or at the species altitudinal limit of distribution to ensure that the chronologies contain high-quality climate information, i.e. a strong climate signal. At all sites, Scots pines were double cored and tree-ring widths were measured with a precision of $0.01 \mathrm{~mm}$. The data were cross-dated and quality checked with the COFECHA software (Holmes et al. 1986). Statistics of the individual chronologies are given in Table 1. For most of the 500 years, the growth patterns of the individual chronologies are well correlated, indicating common growth forcing (Fig. 3). To maximize the common growth variations associated with climate while removing the growth trend, the treering data were standardized (Fritts 1976) using the ARSTAN software (Holmes et al. 1986). Negative exponential functions and, alternatively, regression lines were used in the standardization process to allow for interannual-to-centennial climate information to be retained in the chronologies. The standardized tree-ring chronologies are shown in Fig. 3.

\section{Climate data}

Since the aim was to capture the regional precipitation signal in the tree-ring data, the precipitation data used for calibrating the model were gridded data from 'gu23wld0098.dat' (Version 1.0) constructed and supplied by Dr Mike Hulme at the Climatic Research 
Fig. 2. Climographs for sites close to the studied tree-ring sites. Bars indicate monthly precipitation sums and lines monthly average temperature averaged over the period 1961-1990. A. Trondheim/ Selbu; B. Duved; C. Östersund. See Fig. 1 for locations of the stations.
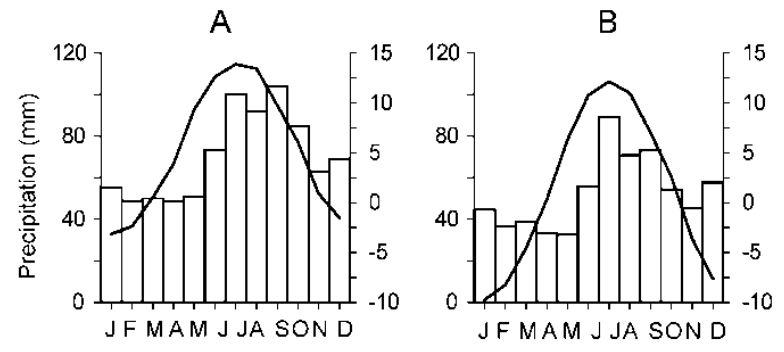

Unit, University of East Anglia, Norwich, UK (work supported by the UK Department of Environment, Transport and the Regions, Contract EPG 1/1/85). This precipitation data set for global land areas, covering the period 1900 to 1998 , is gridded at $2.5^{\circ}$ latitude by $3.75^{\circ}$ longitude resolution. Precipitation data from grid points $62^{\circ} 30^{\prime} \mathrm{N}, 11^{\circ} 15^{\prime} \mathrm{E}$ (Norway) and $62^{\circ} 30^{\prime} \mathrm{N}$, $15^{\circ} 00^{\prime} \mathrm{E}$ (Sweden) were selected. Correlation between the two precipitation records was 0.60 (annual, 19001998), indicating a satisfactory degree of climatic homogeneity. The Norwegian and Swedish records were averaged in order to create a record that better represented the region covered by tree-ring data.

\section{Analysis of the pine growth-precipitation relationship}

To average the chronologies into large-scale patterns, to enhance the variance common to all chronologies, principal components analysis (PCA) was performed on the three standardized tree-ring width chronologies. PCA transforms a set of correlated variables to a new set of uncorrelated variables, where the new variables, PCs, are linear combinations of the original variables. To establish the relationship between PCs 1-3 (Fig. 4) and precipitation, correlation analyses were performed whereby the monthly total precipitation from September of the year preceding growth to August of the growth year was related to PCs 1-3 in the period from 1901 to 1998.
The model to reconstruct precipitation was initially calibrated using half of the available data in the 20th century. Usually, the data for calibration and verification are divided in half, so that first the data from the early part of the period covered by predictors and predictands are used for calibration, the data from the latter part being withheld for verification, and then the procedure reversed. However, in order to include climate variation over the whole period in the calibration and verification of the model, we divided the data set into odd and even years to evaluate models. Odd years were selected for the first calibration and verified with even years; for the second calibration, even years were used for calibration and odd years for verification. The final model used to reconstruct $P_{w}$ back to 1500 was derived from regression over the full 1901-1998 period.

\section{Results}

The percentages of variance explained by the three PCs, which express the variance held in common by the three chronologies included in the analysis, were PC1: 52\%, PC2: $28 \%$ and PC3: $20 \%$. Correlation analyses disclosed a relationship between precipitation and PCs 2 and 3, being strongest for PC2 (Table 2). Significant positive correlations were found with precipitation during winter, but also a negative (significant) correlation in August. Consequently, PCs 2 and 3 were regarded as suitable for reconstructing winter (here: September-April) precipitation. Given that PC2 and

Table 1. Chronology statistics for the standardized tree-ring width chronologies used in the study.

\begin{tabular}{|c|c|c|c|c|c|c|c|c|c|c|}
\hline & $\begin{array}{l}\text { Length of } \\
\text { chronology }\end{array}$ & $\begin{array}{l}\text { Elevation } \\
\text { (m a.s.l.) }\end{array}$ & Lat. (N) & Long. (E) & MS & SD & $1 \mathrm{PC} \%$ & SNR & $\mathrm{R}^{*}$ & No trees \\
\hline I. & $1500-2000$ & 425 & $63^{\circ} 15^{\prime}$ & $10^{\circ} 37^{\prime}$ & 0.15 & 0.21 & 36.10 & 1.20 & 0.30 & 26 \\
\hline II. & 1472-1998 & 700 & $63^{\circ} 07^{\prime}$ & $13^{\circ} 20^{\prime}$ & 0.16 & 0.28 & 43.90 & 4.29 & 0.40 & 38 \\
\hline III. & 1471-1999 & 270 & $63^{\circ} 59^{\prime}$ & $16^{\circ} 32^{\prime}$ & 0.13 & 0.25 & 49.04 & 3.27 & 0.45 & 34 \\
\hline
\end{tabular}

MS = Mean sensitivity, a measure of the relative change in ring-widths from one year to the next.

$\mathrm{SD}=$ Standard deviation

$1 \mathrm{PC} \%=$ The percentage of variation explained by the first principal component expresses the variation held in common among the trees included in the chronology.

$\mathrm{SNR}=$ Signal to noise ratio, measurement of the degree to which the chronology signal is expressed when tree-ring series are averaged. $\mathrm{R}^{*}=$ Mean correlation between trees. 

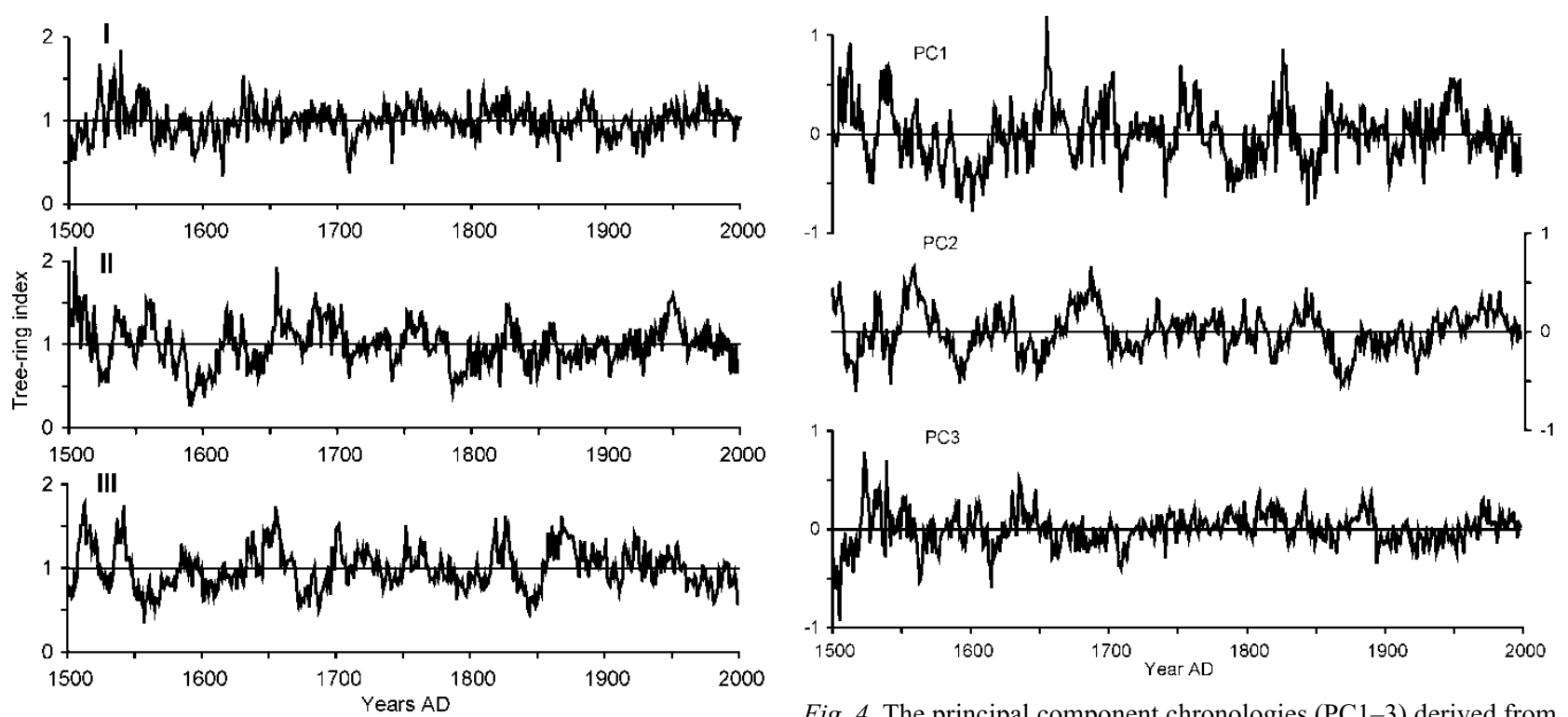

Fig. 3. The standardized tree-ring chronologies used in this study. For locations of the chronologies, see Fig. 1.

PC3 together explain only $48 \%$ of the common variance in the three chronologies, it was not expected that they would be able to capture the full variability of winter precipitation (henceforth referred to as $\mathrm{P}_{\mathrm{w}}$ ) in the 20th century. Correlation between $\mathrm{P}_{\mathrm{w}}$ and PCs 2 and 3 was 0.42 and 0.39 (significant at the 0.05 level), respectively, in the period from 1901 to 1998. Combining PCs 2 and 3 gave a slightly higher correlation (0.46). Figure 5 shows measured $\mathrm{P}_{\mathrm{w}}$ versus modelled $\mathrm{P}_{\mathrm{w}}$ using PC2 and PC3 as predictors with a multiple linear regression model. It is evident that the model fails to capture much of the interannual variability in $\mathrm{P}_{\mathrm{w}}$; only $20 \%$ of the variance in the measured $\mathrm{P}_{\mathrm{w}}$ is accounted for by the model. However, since there was a similarity between measured and modelled $\mathrm{P}_{\mathrm{w}}$ at lower frequencies, coherency analysis (e.g. Chen \& Hellström 1999) was applied to the data to find out if there was another frequency where the association between $\mathrm{P}_{\mathrm{w}}$ and PCs 2 and 3 was higher. The coherency, which can be interpreted as correlation coefficient between the two time series as a function of frequency, was computed according to Brockwell \& Davis (1991). There were differences in the coherency on frequencies of between 1 and 4 years between PC2 and PC 3 , but at around 5 years both PCs displayed

Fig. 4. The principal component chronologies (PC1-3) derived from three tree-ring-width chronologies from central Scandinavia.

significant coherency with $\mathrm{P}_{\mathrm{w}}$ (Fig. 6). Consequently, to reconstruct $\mathrm{P}_{\mathrm{w}}$ with the highest possible resolution, 5 -year means would yield the best results and in further analyses we used the PC chronologies filtered with a Gaussian filter corresponding to a 5-year average. The correlation analyses disclosed a stronger relationship between PCs $2-3$ and precipitation using filtered data (Table 3). Correlation was significant and positive in five (PC2) and six (PC3) of eight winter months. Outside winter, there was a strong (significant) negative correlation between PCs 2-3 and August precipitation. Correlation between filtered $\mathrm{P}_{\mathrm{w}}$ and PCs 2 and 3 was 0.61 and 0.64 (significant at 0.05 level), respectively, in 1905-1994, and combining PCs 2 and 3 gave a correlation coefficient of 0.88 .

The model to reconstruct $\mathrm{P}_{\mathrm{w}}$ was initially calibrated using odd years $(1905,1907$, etc.) in the 20th century, the even years $(1906,1908$, etc.) being withheld for verification in 1950-1994, and then the procedure was reversed. Statistics of the model are given in Table 4. The calibration/verification procedure with filtered data showed a coherent relationship between filtered PCs 23 and $P_{w}$ over the 20th century. The final model used to reconstruct $P_{w}$ back to 1500 was derived from regression over the period 1905-1994, where the model

Table 2. Correlation coefficients for comparison between PCs 1 to 3 and monthly precipitation from September of the year prior to growth to August of the growth year. Only significant (0.05 level) values are shown. The analysed period is 1901-1998.

\begin{tabular}{|c|c|c|c|c|c|c|c|c|c|c|c|c|}
\hline & Sep & Oct & Nov & Dec & Jan & $\mathrm{Feb}$ & Mar & Apr & May & Jun & Jul & Aug \\
\hline PC1 & & & & & & -0.18 & & & & & & \\
\hline PC2 & & & 0.39 & 0.21 & & & & 0.23 & & & & -0.27 \\
\hline PC3 & 0.21 & & 0.29 & & & & & 0.22 & & & & \\
\hline
\end{tabular}




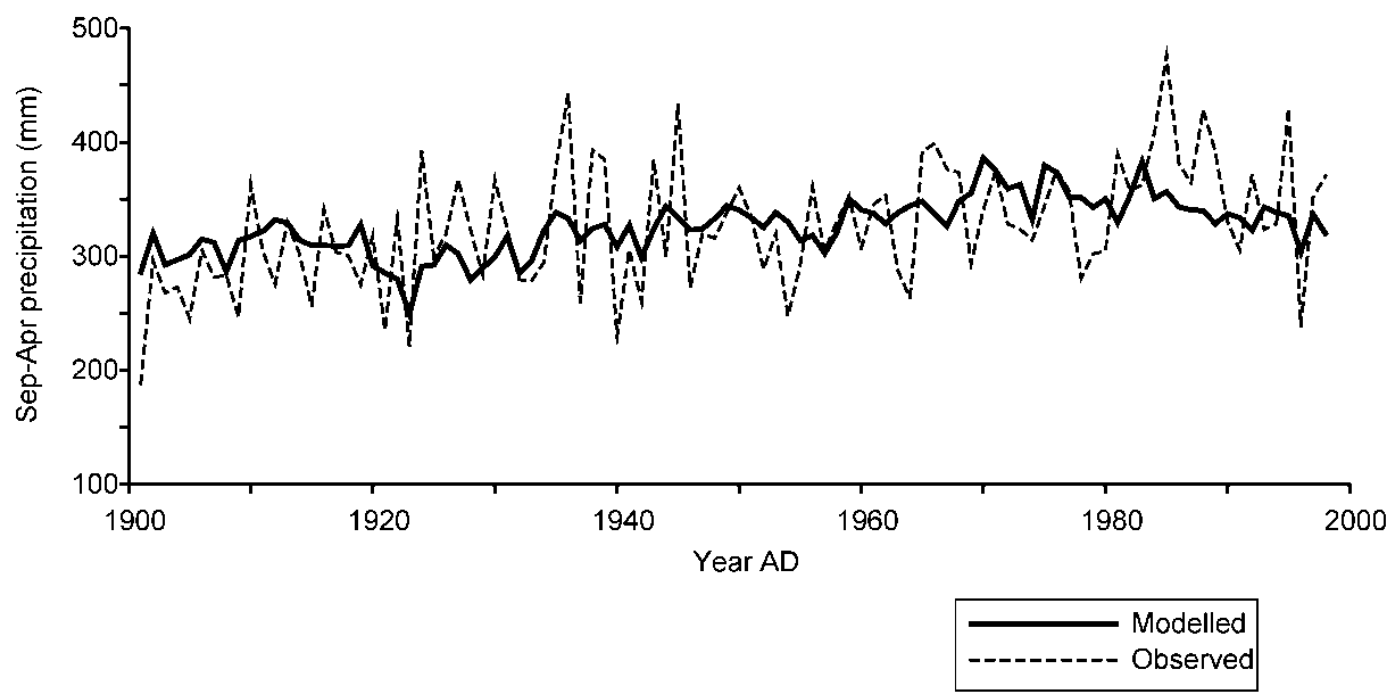

Fig. 5. A comparison between reconstructed (solid line) and measured (dotted line) winter precipitation $\left(\mathrm{P}_{\mathrm{w}}\right)$ in the 20th century. Pw was reconstructed using regression with PC2 and PC3. Correlation between the two records was 0.46 and the variance in $\mathrm{P}_{\mathrm{w}}$ explained by PC2 and PC3 was 0.20 .

explained almost $45 \%$ of the variance in measured $\mathrm{P}_{\mathrm{w}}$. The final reconstruction of $\mathrm{P}_{\mathrm{w}}$ spans $1504-1994$ (Fig. 7). The record shows considerable variability, especially in the 16 th and 17 th centuries. The period with least variability was found in the latter half of the 18th century. Above average $\mathrm{P}_{\mathrm{w}}$ occurred in 15201561 (with a drop below average in the mid-1540s), 1626-1647, 1670-1695, 1732-1851, 1872-1892 and 1959 to the present. Below average $\mathrm{P}_{\mathrm{w}}$ occurred in 1504-1520, 1562-1625 (except 1600-1610), 1648$1669,1696-1731,1852-1871,1893-1958$. The driest winters, disregarding the absolute beginning of the record, were found at the beginning of the 17th century, whereas the last half of the 20th century seems to have been the wettest, at least in the past 400 years.

\section{Discussion}

\section{Comparison with other proxies}

Several inferences about wet and dry phases during the Holocene have been made using a variety of data; peat humification, glacier equilibrium-line altitudes, treelimit distribution variability, occurrence of and treering patterns from subfossil wood, etc. These may be used to evaluate the validity of our $\mathrm{P}_{\mathrm{w}}$ reconstruction. However, it has to be kept in mind that generally these data have a coarser resolution than our reconstruction, which means that the comparison should be made over longer (e.g. decadal to century scale) periods. Thus, by comparing our reconstruction with low-resolution data, we can obtain indications of the precision of the large-scale variability of our work. Figure 8 shows a comparison between our winter precipitation reconstruction and previously postulated wet periods and wet shifts in north-western Europe (e.g. Hughes et al. 2000). Owing to the differences in resolution, it is difficult to draw far-reaching conclusions from such a comparison, but a broad similarity between our $\mathrm{P}_{\mathrm{w}}$ reconstruction and the other proxies is evident. The majority of precipitation proxies in the comparison come from peat stratigraphy data, and it should be noted that changes in humification in peat bogs have been interpreted as responses to changes in evaporation, and are thus more likely caused by changes in temperature rather than rainfall fluctuations (Barber et al. 2000). However, since low evaporation occurs during a milder (cooler) climate, it is most likely that in Scandinavia this will be associated with wetter conditions. The two proxies can therefore be compared. Contrary to three records $(2,5$ and 7$)$, our reconstruction

Table 3. Correlation coefficients for comparison between PCs 2 to 3 and monthly precipitation from September of the year prior to growth to August of the growth year. All values have been filtered with a Gaussian filter corresponding to five-year averages. Only significant $(0.05$ level) values are shown. The analysed period is 1906-1994.

\begin{tabular}{|c|c|c|c|c|c|c|c|c|c|c|c|c|}
\hline & Sep & Oct & Nov & Dec & Jan & Feb & Mar & Apr & May & Jun & Jul & Aug \\
\hline PC2 & 0.36 & & 0.36 & 0.57 & & & 0.38 & 0.58 & & 0.21 & 0.15 & -0.56 \\
\hline PC3 & 0.21 & 0.22 & 0.63 & 0.56 & & & 0.39 & 0.48 & & & & -0.51 \\
\hline
\end{tabular}


Table 4. Reconstruction statistics for west central Scandinavian winter (September-April) precipitation. Calibration/verification was tested in 1905-1994 when meteorological data exist, first using odd years $(1905,1907$, etc.) and then even years $(1906,1908$, etc.).

\begin{tabular}{|c|c|c|c|}
\hline $\begin{array}{l}\text { Calibration } \\
\text { Verification }\end{array}$ & $\begin{array}{l}\text { Odd years } \\
\text { Even years }\end{array}$ & $\begin{array}{l}\text { Even years } \\
\text { Odd years }\end{array}$ & Final calibration \\
\hline \multicolumn{4}{|l|}{ Calibration } \\
\hline Variance explained & 0.47 & 0.45 & 0.46 \\
\hline Adjusted $\mathrm{r}^{2}$ & 0.46 & 0.44 & 0.45 \\
\hline Correlation coefficient & 0.69 & 0.67 & 0.68 \\
\hline Reduction of error & $0.47 *$ & $0.45^{*}$ & - \\
\hline Sign test & $39+/ 6-*$ & $38+/ 7-*$ & - \\
\hline Regression equation & $\begin{aligned} \mathrm{P}_{\mathrm{w}}= & 327.5+(68.7 * \mathrm{PC} 2) \\
& +\left(116.5^{*} \mathrm{PC} 3\right)\end{aligned}$ & $\begin{aligned} \mathrm{P}_{\mathrm{w}}= & 329+(53.1 * \mathrm{PC} 2) \\
& +\left(125.5^{*} \mathrm{PC} 3\right)\end{aligned}$ & $\begin{aligned} \mathrm{P}_{\mathrm{w}}= & 328.3+(60.8 * \mathrm{PC} 2) \\
& +(121.2 * \mathrm{PC} 3)\end{aligned}$ \\
\hline \multicolumn{4}{|l|}{ Verification } \\
\hline Correlation coefficient & $0.67 *$ & $0.68 *$ & - \\
\hline Reduction of error & $0.44^{*}$ & $0.47 *$ & - \\
\hline Sign test & $38+/ 7-*$ & $38+/ 7-*$ & - \\
\hline
\end{tabular}

*Significant at $95 \%$ level.
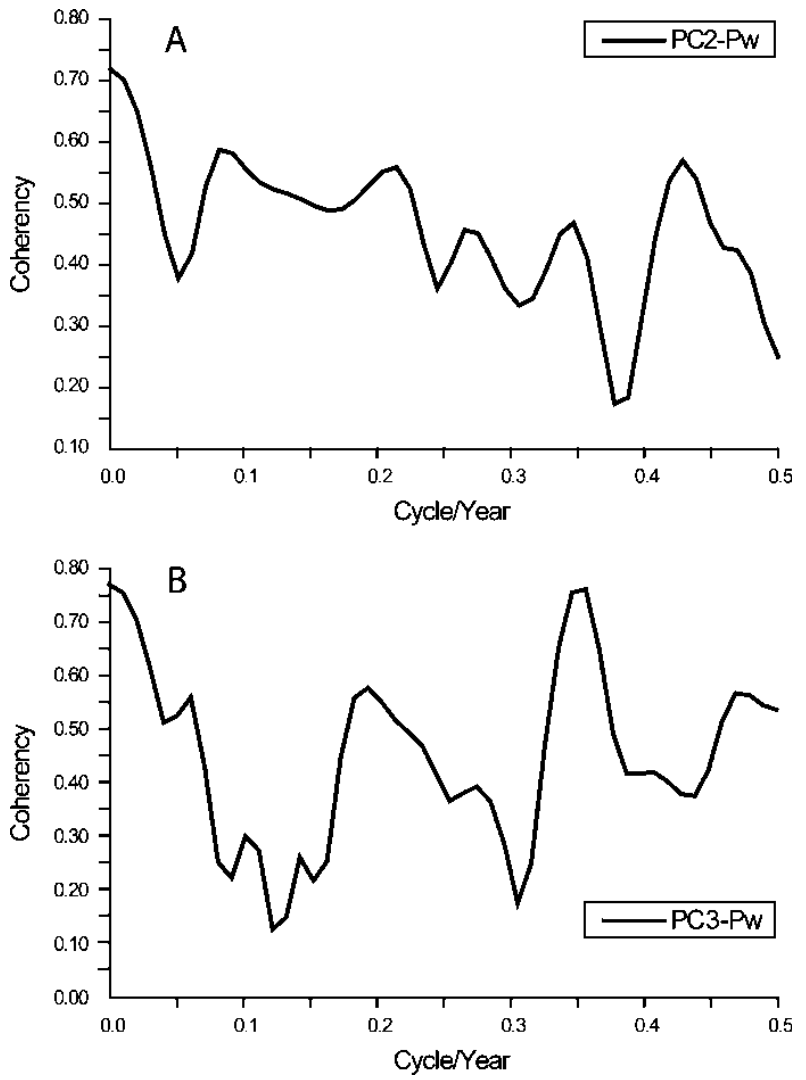

Fig. 6. The coherency spectrum between $\mathrm{P}_{\mathrm{w}}$ and $\mathrm{PC} 2(\mathrm{~A}) ; \mathrm{P}_{\mathrm{w}}$ and $\mathrm{PC} 3$ and (B).

suggests quite a high variability in precipitation from 1500 to the beginning of the 18 th century. It should be noted that some of the high variability in the early part of the record (16th century) may be exaggerated because of fewer, and also younger, trees in the treering data. However, the period of prolonged, above average, precipitation between $c .1730$ and 1850 is well represented in several records, although the onset is earlier in some of them. This could be due to differences in resolution among the records. On the whole, there seems to be a lag between the timing of wet shifts, as inferred from peat stratigraphy, and increases in precipitation, as inferred from the tree rings. This may be an effect of the response of a peatlands water table level to climate, which may lag climate change by several decades (Kilian et al. 1995; D. Charman, pers. comm. 2001). Consequently, by moving the wet events slightly back in time there is a better correspondence with our reconstructed increases in precipitation. Since the majority of climate proxies used in the comparison show wet periods, it is difficult to validate dry periods. Nevertheless, the dry winters at the beginning of the 18 th century (our record) correspond reasonably well with high evaporation for Fallahogy bog, Northern Ireland, as reconstructed from meteorological data (Barber et al. 2000), suggesting that this indeed was a dry period. The records of glacier advances in northern Sweden (1 and 8) periodically agree well with our record, where, generally, advances are preceded by a period of increased winter precipitation. In addition, an agreement can be found between our $\mathrm{P}_{\mathrm{w}}$ reconstruction and periods of favourable/poor pine regeneration in the central Scandinavian Mountains as reconstructed by Kullman (1987), where good seed production is favoured by warm summers and generally dry climatic conditions (Zackrisson et al. 1995). Periods of favourable regeneration conditions in 1660-1680 (early part), 1810-1830, 1850-1860 and 1930-1950 correspond to below average $\mathrm{P}_{\mathrm{w}}$ or a marked decrease in precipitation (1810-1830). Periods of poor regeneration in 1830-1850 and 1880-1890 correspond to above average $\mathrm{P}_{\mathrm{w}}$. However, there are periods when favourable/poor regeneration does not correspond to below/above average $\mathrm{P}_{\mathrm{w}}$ : 1770-1800, 1870-1880 (favourable regeneration, above average $\mathrm{P}_{\mathrm{w}}$ ), and 1680-1720, 1800-1810, 1860-1870 (poor regeneration, below average $\mathrm{P}_{\mathrm{w}}$ ). Furthermore, the increase in winter precipitation in the early 18th century is in line 


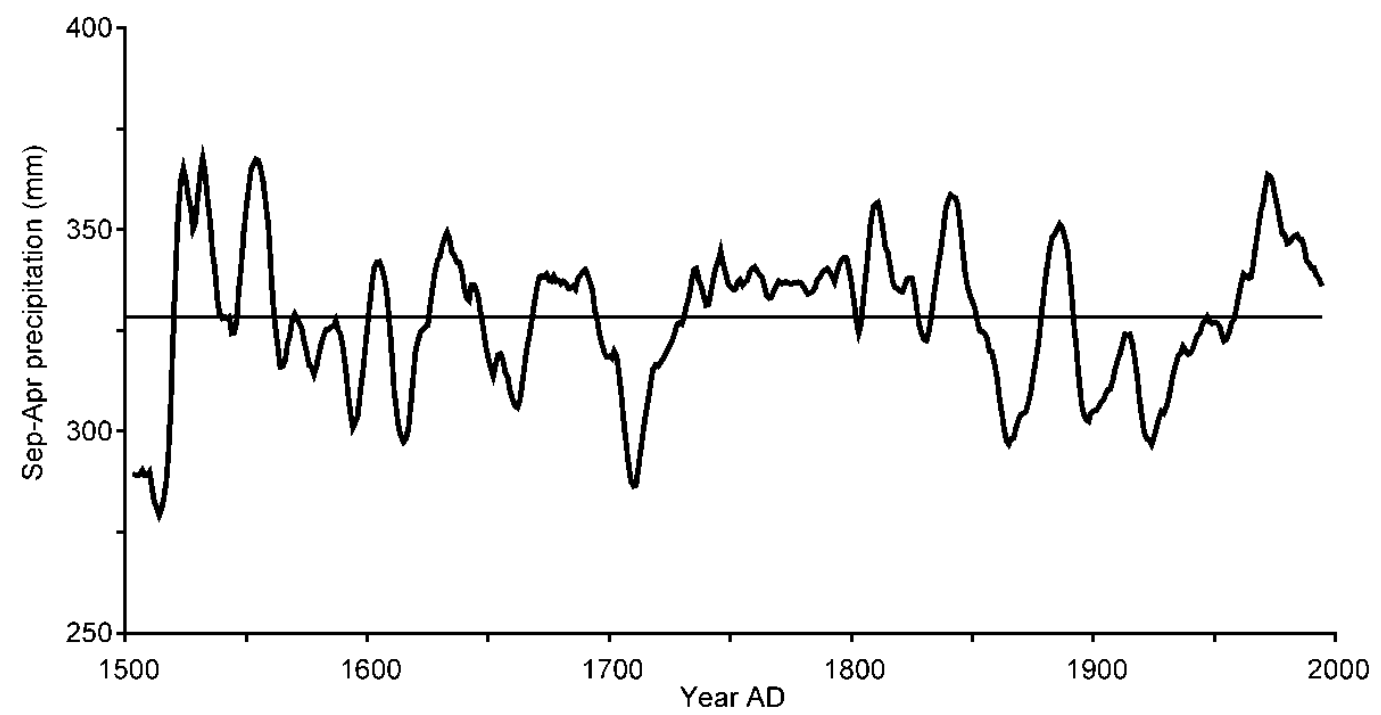

Fig. 7. Central Scandinavian winter (September-April) precipitation reconstructed back to AD 1500. Note that the resolution of the reconstruction is five years. The straight line indicates the mean winter precipitation $(328.5 \mathrm{~mm})$.

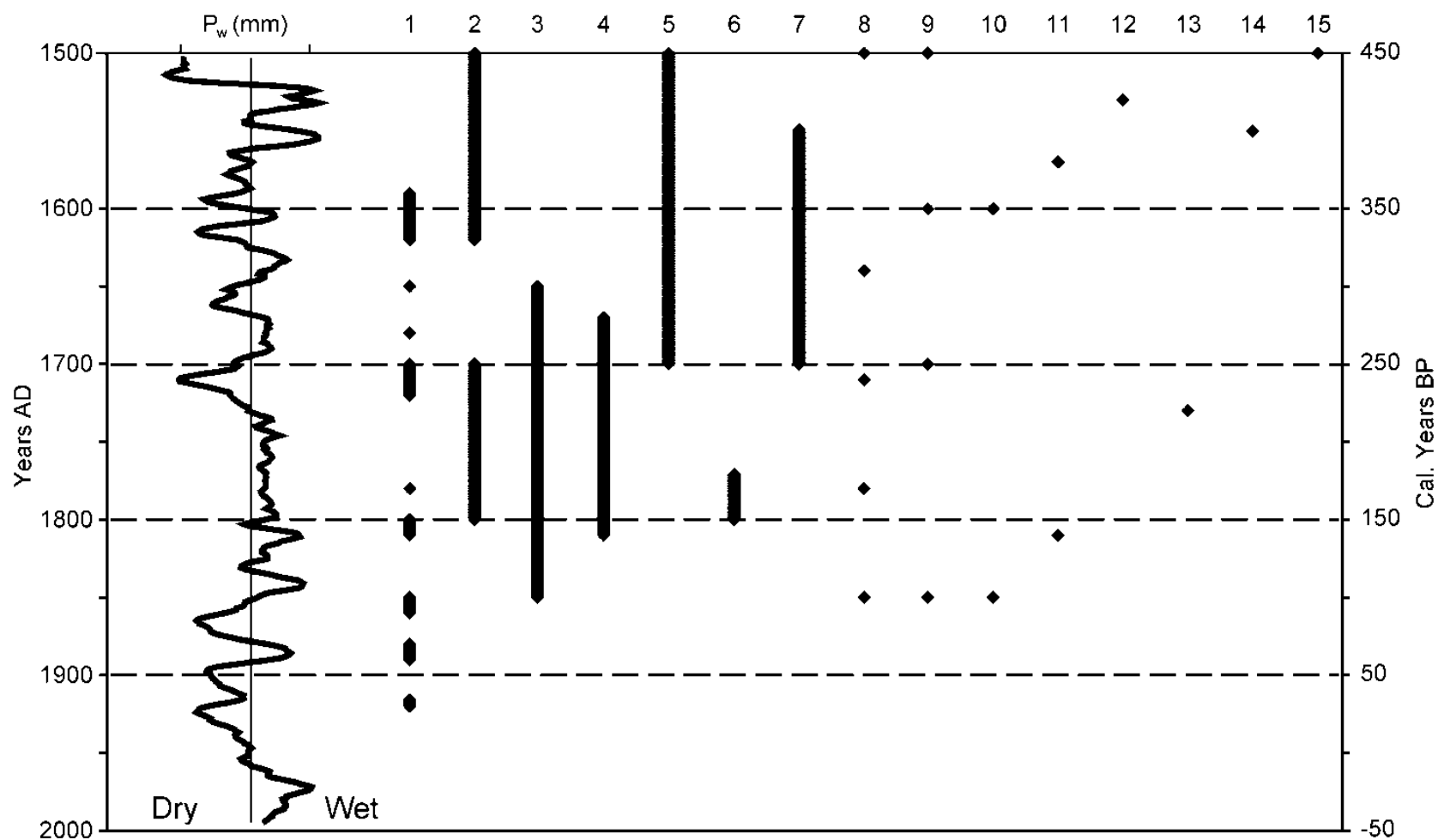

Fig. 8. Central Scandinavian winter precipitation since AD 1500 compared to previously published inferred timings of north European wet shifts and wet periods. 1. Karlén \& Denton (1976): glacier advances, Sarek, Sweden; 2. Chiverell (2001): peat stratigraphy, May Moss, England; 3. Barber et al. (2000): peat stratigraphy, Fallahogy Bog, Northern Ireland; 4. Barber et al. (2000): peat stratigraphy, Moine Mhor, Scotland; 5. Dahl \& Nesje (1996): glacier equilibrium altitudes and pine-tree limits, Norway; 6. Mauquoy \& Barber (1999): peat stratigraphy, The Border Mires, England; 7. Gunnarson et al. (2003): subfossil wood and peat stratigraphy, west central Sweden; 8. Karlén (1973): glacier advances and lichenometry, Sweden; 9. Hohl (2003): peat stratigraphy, west central Sweden; 10. Hughes et al. (2000): peat stratigraphy, Walton Moss, England; 11. Langdon \& Barber (2001): peat stratigraphy, Ben Gorm Moss, Scotland; 12. Nissen \& Vorren (1991): peat stratigraphy, central and northern Norway; 13. Barber (1981): peat stratigraphy; 14. Tipping (1995): peat and pollen stratigraphy, Kirkpatrick Fleming, Scotland; 15. Aaby (1976): peat stratigraphy, Denmark. 


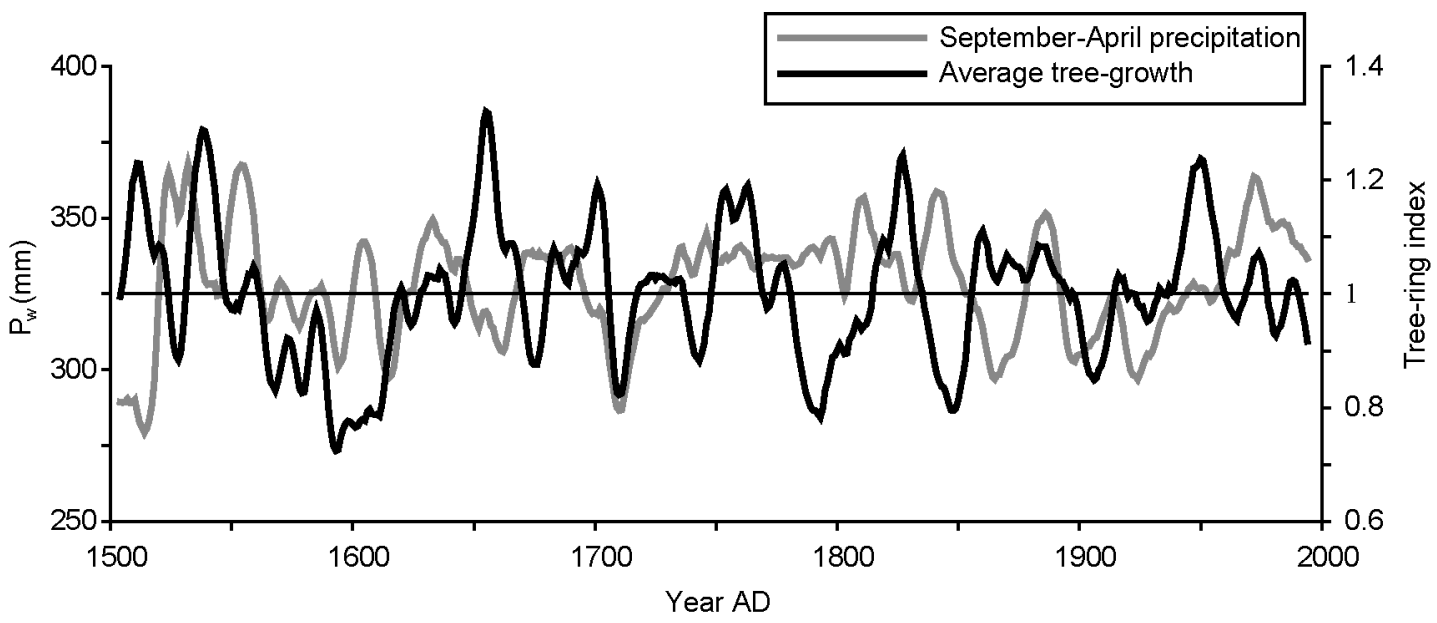

Fig. 9. Reconstructed central Scandinavian winter (September-April) precipitation since AD 1500 compared to a composite Scots pine growth chronology (averaged from sites I to III). The annual growth of Scots pine in the area is mainly limited by summer temperatures (Linderholm et al. 2003).

with the hypothesis put forward by Nesje \& Dahl (2003) for rapid glacier advance in Norway during that period.

\section{Central Scandinavian tree rings as precipitation indicators}

Since this is the first attempt to use tree-ring data to yield high-resolution information on past winter precipitation variability in Scandinavia, where tree rings have previously been used as temperature proxies, the results of this investigation should be viewed with caution. There may be several objections to using high-latitude tree-ring data from this oceanic to subcontinental environment to reconstruct precipitation; especially since summer temperature is the main growth-limiting factor for Scots pine in this area. However, although temperature has proved to have the most influence on pine growth, precipitation too affects pine growth in western Scandinavia (see Kirchhefer \& Vorren 1995; Linderholm 2002), where Scots pine growth patterns contain both temperature and precipitation information. It should be noted that although the correlation between $\mathrm{P}_{\mathrm{w}}$ and PCs $2-3$ is positive, the actual effect on tree growth of large amounts of $P_{w}$ is negative. During periods of strong zonal atmospheric circulation, climate in west central Scandinavia would become more oceanic with increased precipitation and milder temperatures. Large amounts of snow in winter (and lower temperatures in spring) would lead to sustained snow cover lasting well into late spring. This would cause later initiation of cambial activity, as proposed by Vaganov et al. (1999). Furthermore, increasing soil moisture when melting occurs, together with increased spring precipitation, would result in an excess of water, and, periodically, water-saturated soils may cause anoxic conditions (Crawford 2000). The combination of these factors is the likely reason for the winter precipitation response in Scots pine in central Scandinavia. Still, tree-ring data from central Scandinavia cannot provide reconstructions of winter precipitation with interannual resolution. This is probably due to the secondary effect of precipitation on tree growth, but, more importantly, the $\mathrm{P}_{\mathrm{w}}$-pine growth relationship indicates storage of water in the soils before it affects pine growth. Most of the sampled pines at the three sites grow on glacial sediments and tills with quite good water storing capacities, and decreases or increases of the local water table in these soils may not be an instant process, but more likely the result of climate over several years. Provided that these pines respond similarly to trees growing on peat soils, a high water table results in reduced pine growth, as nutrients become less available in a poorly aerated soil (Mannerkoski 1991). In peat, water table variability is a slow process (see above), but is more rapid in glacial sediments and the correspondence between PCs 2-3 and $P_{w}$ variability suggests that in the studied area the changes in the local water table which affect pine growth take approximately five years.

According to the above, phases of high $\mathrm{P}_{\mathrm{w}}$ lead to decreased pine growth, and since variations in the local water table, through evapotranspiration, are dependent on temperature as well, it would be expected that the (negative) effect on pine growth of large amounts of $\mathrm{P}_{\mathrm{w}}$ would be even more pronounced when summers are mild. In Fig. 9, pine growth, averaged for the three sites, is compared to our $\mathrm{P}_{\mathrm{w}}$ reconstruction, where growth is a good approximation of summer temperatures. This comparison discloses that, generally, above average amounts of $\mathrm{P}_{\mathrm{w}}$ correspond to below average growth, and vice versa. However, there are exceptions, e.g. in the late 16th to early 17th century when $P_{w}$ as well as growth are mainly below average. However, this period is considered to be one of the coldest during the Little Ice Age in Scandinavia (see Grudd et al. 2002). 
One factor that weakens the winter precipitation signal in PCs $2-3$ is the additional response to August precipitation. While Scots pine in the studied area would commonly respond with decreased growth to high amounts of precipitation, the positive influences of August precipitation imply that in the late stages of the growing season the soils have dried enough to prompt this response, at least during dry summers (Kirchhefer \& Vorren 1995). Further caution should be taken when assessing our $\mathrm{P}_{\mathrm{w}}$ reconstruction owing to the slightly different climate-growth relationships at the three chronology sites, which will affect the common precipitation signal. Since the three sites are situated in a gradient across the Scandinavian Mountains from oceanic to subcontinental, growth responses to precipitation will undoubtedly vary through time at, as well as among, the different sites (see Fig. 2). Consequently, the accuracy of the reconstruction may also vary in time. But since there are no meteorological or reliable high-resolution precipitation proxies extending beyond the 20th century, the quality of the reconstruction is difficult to assess. Nevertheless, looking at decadal resolution, we feel that our reconstruction could provide additional information when examining temporal precipitation variability on a regional scale. In order to gain knowledge about past precipitation variability, several proxies must be combined, and treering data could well be one contender.

\section{Conclusions}

Using PCA on Scots pine tree-ring data from central Scandinavia it is possible to extract useful information about regional winter (September-April) precipitation variability, especially on semi-decadal time scales. Our reconstruction shows large variability between wet and dry winters, especially in the first two centuries of the record; the driest winters, disregarding the absolute beginning of the record, were found at the beginning of the 18 th century. Winters from the mid-18th century to the mid-19th century were predominantly wet, and the last half of the 20th century seems to have been the wettest in the past four centuries. Since summer temperature is the main limiting growth factor for Scots pine in the region, our reconstruction should be viewed with some caution. However, a fairly good agreement with previously published precipitation proxies (generally with coarser resolution) suggests that Scots pine tree-ring data can add useful information to, and be included in, future multi-proxy precipitation reconstructions.

Acknowledgements. - This work was supported by Ahlmanns fond, Lagrelius fond, Mannerfelts fond, SSAG and EU project ENV4CT95-0127. We acknowledge the field assistance of Björn Gunnarson and Bård Solberg and we thank K. E. Barber and one anonymous reviewer for their helpful comments.

\section{References}

Aaby, B. 1976: Cyclic climatic variations in climate over the past $5,500 \mathrm{yr}$ reflected in raised bogs. Nature 263, 281-284.

Barber K. E. 1981: Peat Stratigraphy and Climatic Change-a Palaeoecological Test of the Theory of Cyclic Peat Bog Regeneration. 219 pp. A. A. Balkema, Rotterdam.

Barber, K. E., Maddy, D., Rose, N., Stevenson, A. C., Stoneman, R. \& Thompson, R. 2000: Replicated proxy climate signals over the last $2000 \mathrm{yr}$ from two distant UK peat bogs: new evidence for regional palaeoclimatic teleconnections. Quaternary Science Reviews 19, 481-487.

Brockwell, P. J. \& Davis, R. A. 1991: Time Series: Theory and Methods. 577 pp. Springer, New York.

Busuioc, A., Chen, D. \& Hellström, C. 2001: Temporal and spatial variability of precipitation in Sweden and its link with the largescale atmospheric circulation. Tellus 53A, 348-367.

Chen, D. \& Hellström, C. 1999: The influence of the North Atlantic Oscillation on the regional temperature variability in Sweden: spatial and temporal variations. Tellus 51A, 505-516.

Chiverrell, R. C. 2001: A proxy record of late Holocene climate change from May Moss, northeast England. Journal of Quaternary Science 16, 9-29.

Crawford, R. M. M. 2000: Ecological hazards of oceanic environment. New Phytologist 147, 257-281.

Crowley, T. J. 2000: Causes of climate change over the past 1000 years. Science 289, 270-277.

Dahl, S. O. \& Nesje, A. 1996: A new approach to calculating Holocene winter precipitation by combining glacier equilibrium altitudes and pine-tree limits: a case study from Hardangerjøkulen, central southern Norway. The Holocene, 381-398.

Esper, J., Cook, E. R. \& Schweingruber, F. H. 2002: Low-frequency signals in long tree-ring chronologies for reconstructing past temperature variability. Science 295, 2250-2253.

Fritts, H. C. 1976: Tree-Rings and Climate. 567 pp. Academic Press, London.

Grudd, H., Briffa, K. R., Karlén, W., Bartholin, T. S., Jones, P. D. \& Kromer, B. 2002: A 7400-year tree-ring chronology in northern Swedish Lapland: natural climate variability expressed on annual to millennial time scales. The Holocene 12, $657-665$.

Gunnarson, B. E. \& Linderholm, H. W. 2002: Low frequency climate variation in Scandinavia since the 10th century inferred from tree rings. The Holocene 12, 667-671.

Gunnarson, B. E., Borgmark, A. \& Wastegård, S. 2003: Holocene humidity fluctuations in Sweden inferred from dendrochronology and peat stratigraphy. Boreas 32, 347-360.

Hanssen-Bauer, I. \& Førland, E. J. 1998: Annual and Seasonal Precipitation Variations in Norway 1896-1997. DNMI report 28/98, klima, Norwegian Meteorological Institute, Oslo.

Hohl, V. 2003: Klimatförändringar under de senaste 6500 åren, humifieringsförändringar $i$ torv från Lilla Backsjömyren i Jämtland. M.Sc. thesis, Stockholm University, $31 \mathrm{pp}$.

Holmes, R. L., Adams, R. K. \& Fritts, H. C. 1986: Tree-ring chronologies of western North America: California, eastern Oregon and northern Great Basin, with procedures used in the chronology development work, including user manuals for computer programs COFECHA and ARSTAN, Chronology Series VI. Laboratory of Tree-Ring Research, University of Arizona, Tucson, 50-65.

Hughes, P. D. M., Mauquoy, D., Barber, K. E. \& Langdon, P. G. 2000: Mire-development pathways and palaeoclimatic records from a full Holocene peat archive at Walton Moss, Cumbria, England. The Holocene 10, 465-479.

IPCC 2001: Climate Change 2001: Impacts, Adaptation and Vulnerability. Contribution of Working Group I to the Third Assessment Report of the Intergovernmental Panel of Climate Change. Cambridge University Press, Cambridge. 
Jones, P. D., Osborn, T. J. \& Briffa, K. R. 2001: The evolution of climate over the last millennium. Science 292, 662-667.

Kalela-Brundin, M. 1999: Climatic information from tree-rings of Pinus sylvestris L. and a reconstruction of summer temperatures back to AD 1500 in Femundsmarka, eastern Norway, using partial least squares regression (PLS) analysis. The Holocene 9, 59-77.

Karlén, W. 1973: Holocene glacier and climatic variations, Kebnekaise mountains, Swedish Lapland. Geografiska Annaler $55 A, 29-63$.

Karlén, W. \& Denton, G. H. 1976: Holocene glacial variations in Sarek National Park, northern Sweden. Boreas 5, $25-56$.

Kilian, M. R., Van der Plicht, J. \& Van Geel, B. 1995: Dating raised bogs. New aspects of AMS ${ }^{14} \mathrm{C}$ wiggle matching, a reservoir effect and climatic change. Quaternary Science Reviews 14 959-966.

Kirchhefer, A. J. 1999: Dendroclimatology on Scots pine (Pinus sylvestris L.) in northern Norway. Ph.D. dissertation, University of Tromsø, $116 \mathrm{pp}$.

Kirchhefer, A. J. \& Vorren, K.-D. 1995: Åringer på furu, Pinus sylvestris L., som kilde for klimatinformasjon i Vesterålen, NordNorge. AmS-Varia 24, 79-85.

Kullman, L. 1987: Little Ice Age decline of a cold marginal Pinus sylvestris forest in the Swedish Scandes. New Phytologist 106, 567-584.

Kullman, L. 1991: Cataclysmic response to recent cooling of a natural boreal pine (Pinus sylvestris L.) forest in northern Sweden. New Phytologist 117, 351-360.

Langdon, P. G. \& Barber, K. E. 2001: New Holocene tephras and a proxy climate record from a blanket mire in northern Skye, Scotland. Journal of Quaternary Science 16, 753-759.

Linderholm, H. W. 2002: Twentieth-century Scots pine growth variations in the central Scandinavian Mountains related to climate change. Arctic, Antarctic, and Alpine Research 34, 440-449.

Linderholm, H. W., Solberg, B. Ø. \& Lindholm, M. 2003: Tree-ring records from central Fennoscandia: the relationship between tree growth and climate along an east west transect. The Holocene 13, 887-895.

Mann, M. E., Bradley, R. S. \& Hughes, M. K. 1999: Northern Hemisphere temperatures during the past millennium: inferences, uncertainties and limitations. Geophysical Research Letters 26, $759-762$.
Mann, M. E. \& Jones, P. D. 2003: Global surface temperatures over the past two millennia. Geophysical Research Letters 30, 1820. DOI: $10.1029 / 2003 \mathrm{GL} 017814$.

Mannerkoski, H. 1991: Relation between tree roots and soil aeration on drained peatlands. In Jeglum, J. K. \& Overend, R. P. (eds.): Peat and Peatlands - Diversification and Innovation, 109-114. Canadian Society for Peat and Peatlands, Canada.

Mauquoy, D. \& Barber, K. E. 1999: A replicated $3000 \mathrm{yr}$ proxyclimate record from Coom Rigg Moss and Felicia Moss, the Border Mires, northern England. Journal of Quaternary Science 14, 263-275.

Mysterud, A., Yoccoz, N. G., Stenseth, N. C. \& Langvatn, R. 2000: Relationship between sex ratio, climate and density in red deer: the importance of spatial scale. Journal of Animal Ecology 69, 959-974.

Nesje, A. \& Dahl, S. O. 2003: The 'Little Ice Age' - only temperature? Holocene 13, 139-145.

Nissen, E. \& Vorren, K.-D. 1991: Peat humification and climate history. Norsk Geologisk Tidsskrift 71, 215-217.

Solberg, В. Ø., Hofgaard, A. \& Hytteborn, H. 2002: Shifts in radial growth responses of coastal Picea abies induced by climatic change during the 20th century, Central Norway. Ecoscience 9, 79-88.

Thomsen, G. 2001: Response to winter precipitation in ring-width chronologies of Pinus sylvestris L. from the northwestern Siberian plain, Russia. Tree-Ring Research 57, 15-29.

Tipping, R. 1995: Holocene evolution of a lowland Scottish landscape: Kirkpatrick Fleming. Part I, peat- and pollen-stratigraphic evidence for raised moss development and climatic change. The Holocene 5, 69-81.

Tranquilini, W. 1979: Physiological Ecology of the Alpine Timberline. Tree Existence at High Altitudes with Special References to the European Alps. Ecological Studies 31. Springer Verlag, Berlin.

Tuomenvirta, H., Alexandersson, H., Drebs, A., Frich, P. \& Nordli, P. O. 2000: Trends in Nordic and Arctic temperature extremes and ranges. Journal of Climate 13, 977-990.

Vaganov, E. A., Hughes, M. K., Kirdyanov, A. V., Schweingruber, F. H. \& Silkin, P. P. 1999: Influence of snowfall and melt timing on tree growth in subarctic Eurasia. Nature 400, 149-151.

Zackrisson, O., Nilsson, M. C., Steijlen, I. \& Hörnberg, G. 1995: Regeneration pulses and climate-vegetation interactions in nonpyrogenic boreal Scots pine stands. Journal of Ecology 83, $469-483$ 